AN INTERNATIONAL JOURNAL OF ARTS AND HUMANITIES

(IJAH)

Bahir Dar, Ethiopia

Vol. 3 (3), S/No 11, July, 2014: 47-60

ISSN: 2225-8590 (Print) ISSN 2227-5452 (Online)

DOI: http://dx.doi.org/10.4314/ijah.v3i3.5

\title{
DEMOCRACY AND SUCCESSION PROBLEMS IN NIGERIA: THE FOURTH REPUBLIC EXPERIENCE
}

\author{
Olaniyi, Lamidi Kamal \\ Department of Political Science, \\ Federal University, Dutse, Jigawa State, Nigeria \\ E-mail: Olanka78@gmail.com \\ \& \\ Umar, Mohammed Bello \\ Department of Political Science, \\ Federal University, Dutse, Jigawa State, Nigeria \\ E-mail: dr.mbumar@yahoo.com
}

\begin{abstract}
Leadership succession is the problem facing Nigeria since 1960. The mode of transfer power from one government to another is always accompanied by tension. This tension is anchored on the fact that leaders are imposed. The problem has been attributed to the persistent interruption by the military, since 1960. With inception of democracy in 1999, there was positive hope about leadership succession in the country, but the reverse was the result as all elections conducted were seriously accompanied by tensions. It is against this background, that this paper examines the challenges of succession in Nigeria's fourth republic. The paper also revealed that
\end{abstract}


despite the potential of democracy in ensuring smooth power transfer, the failure of political leaders to observe the rules guiding the process portrays democracy as an incompetent system. It is also reveals that the majority of politicians did not believe in the ethos of democracy. Therefore, the paper has concluded that orderly transfer of power depends on the wishes of political leaders, and for succession to be orderly; the paper recommends that all the parties involved in the process of conducting political processes should be committed to the rules of the game.

Key words: Democracy, Election, Succession, Tension

\section{Introduction}

Good governance is a product of leaders that are freely and popularly elected and not imposed. Well-planned and managed succession brings stability, predictability and continuity in governance. The basic assumption here is that orderly change of government has multi faceted advantages. Over the centuries, scholars have been proud of the fact that democratic system of government assures a peaceful transition from one set of officials to another (Baffour, 2003). Public office is not the property of incumbents but theoretically belongs to the citizens who can reclaim it in an orderly, peaceful way. Thus, the credibility of these arguments depends upon the existence of choice among candidates and politics.

Elections play a significant role in deepening democracy, it enable the governed to decide who governs them. Credible elections therefore remain a salient indicator of democratic consolidation and peaceful means of changing government. Thus, it is a universally accepted tool for selecting representatives. The Commission on Human Rights Resolution 2003/35, para 9 thus asserted that:

The will of the people shall be the basis of the authority of government and... This shall be expressed in periodic and genuine elections which shall be by universal and equal suffrage and shall be held by secret vote or by equivalent free voting procedures (Goodwin-Gill, 2006).

In line with the above statement, all regions of the world conduct elections, but not just any elections, are hallmarks of democracy and thus important instruments through which leaders are elected to public office. The essence of election was recognized by the international community to the extent that it established international criterion or benchmark to be embraced (IPU, 1994). In establishing relationship between leadership stability and potentiality for development in a state, Anise (1974) and Goldsmith (2000) identified five types of leadership succession in Africa as: assassination, coup d'état, abdication and or resignation, and constitutional 
procedures. Failure to effectively manage any of these types can result in succession crisis. For the purpose of this work, constitutional procedure is adopted as an instrument of analysis.

In Nigeria, the fundamental problem of the democratization process is the conduct of free and fair and acceptable elections. Virtually all the elections conducted so far in the history of Nigerian politics have been characterized by diverse forms of electoral irregularities. For instance, the 1959 election was unacceptable by most of the opposition parties. Meanwhile, the determination to gain independence reduced the tension that such outcome might bring. The 1963/64 elections were also beset with irregularities especially in the Western region and middle belt which contributed to the collapse of the First Republic (Anifowose, 2006). Misinterpretation of constitutional provision by political parties and failure of politician to obey the rules of the game created crisis which eventually led to collapse of the second republic in 1983.

The 1993 elections adjudge as the freest and fairest, were annulled by the military government of General Ibrahim Babangida. The reasons behind this annulment coupled with economic crisis left the Nigerians with no choice than to end military rule by ushering in the 1999 elections. The preceding elections in 2003, 2007, and 2007 were widely acclaimed to be massively fraudulent. Therefore, this paper examines the basic democratic principles that guard the process of power transfer, causes of succession problems in Nigeria and its implications on Nigerian democracy.

\section{Succession}

Succession means orderly transfer of political power from one group to another. Orderliness in the process of power transfer is also used in determining the level of state maturity. It also acts as a barometer for accessing both the consolidation and the quality of democracy in a polity at any particular point (Ojo, 2007a). Democracy is about free choice, it is about given people opportunities to choose their leaders without hindrance, but where obstacles exist, the people can hardly exercise their freedom of choice and in such situation they can hardly gain anything from their rulers (Egwemi, 2010). The strength of the idea of democracy lies in the principle of people's participation in their governance. Thus, democratic regimes tend to be responsive to the collective needs of society due to periodic changes in governments and personalities (Hameso, 2002).

On this note, Ojo (2007b) posited that democracy has an educative value and there is no better way of educating citizens than giving them the opportunity to participate directly in the election of their representatives. And for representative government to be democratic, it must be accompanied by universal free suffrage, elections, short 
terms of office and individual liberty (Mills, 1975). As rightly observed Baffour (2003), "Orderly political succession through the ballot box and peaceful alternation of power are the hallmarks of effective democratization." And, "to sustain democracy and good governance in Africa, there is the need for strategic thinking on succession management from the political, corporate, traditional and social perspectives. Orderly successions are democratic if they are free, fair, participatory, competitive and legitimate. Thus, successions to Diamond (2008) are orderly

...when they are administered by a neutral authority; when the electoral administration is sufficiently competent and resourceful to take specific precautions against fraud; when the police, military and courts treat competing candidates and parties impartially; when contenders all have access to the public media; when electoral districts and rules do not grossly handicap the opposition.... when the secret of the ballot is protected; when virtually all adults can vote; when procedures for organizing and counting the votes are widely known; and when there are transparent and impartial procedures for resolving election complaints and disputes.

Once these basic standards are met, then the succession is orderly. In the view of Bratton and Posner (1999) elections provide the best means of orderly leadership succession in a liberal democracy. According to them, elections serve as platforms for popular participation in political developments adding that it also made government responsible and responsive. But, when government failed to be responsible and responsive and block mechanism for peaceful transition, then people engage in violent.

\section{The Determinants of Orderly Change of Government in a Democratic Regime}

Conventionally, democratic politics regards periodic elections as an instrumental value which must be institutionalized. This is because, without them being held regularly and seen to be conducted in a transparently free and fair manner, democracy remains a sham (Enojo, 2010). Free and fair elections promote accountability in elected officials, socialize political activity and expand citizens' involvement. They guarantee a stable polity, reduce conflict and restore confidence in the government and the state (Ijim-Agbor, 2004). The requirements for the conduct of a free and fair election, is the state's capacity to achieve it. In a situation where the state is weak, the hope of an orderly succession becomes a mirage. The state power, according to Johari (1978) is said to consist of the following five elements: monopoly of the coercive power of society that is control of the instruments of coercion; the right to impose 
taxes and collect revenue; the power to make laws; sovereignty over territory; and control of the institutions of the state. All these elements are the major pillar upon which orderly succession rest.

In setting out the requirements for an orderly change of government, Mackeaze (1958) argued that effective functioning of a competitive electoral system requires the following;

i. An independent judiciary to interpret the electoral law

ii. An honest, competent, non-partisan administration to run elections

iii. A well developed system of political parties organized to put their policies and teams of candidates before the electorate.

iv. A general acceptance by the political community of certain rather vague rules of the game, which limit the struggle for power.

Almond and Verbal (1963) posited that facilitating factors are the norms, traditions and attitudes of social cooperation and interpersonal trust and high levels of consensus which must permeate the political process. In this vein, Aron cited in Anifowose (2003) declared that what is necessary for competition between parties is that the two different parties should accept the rules of the game, that they should have the feelings that the unity of the nation is good, in itself, which should be maintained and the assurance that whoever wins an election will be allowed to assume office. Outcomes of elections must therefore be irreversible under a democracy even if the opposition or a less popular party wins in a free and fair contest.

\section{An Overview Democratic Succession in Nigerian}

The process of changing government right from first republic was marked with irregularities to the extent that the legitimacy of emerged government was questioned. For instance, the elections conducted in 1964 at both federal and the regional level were extremely controversial; parties and some key political leaders hired thugs to beat up people and intimidate them; Kidnap or murder of political opponents (Iyayi, 2007). Dudley (1982) reported that the electoral officers were terrorized into absconding from their offices once they receive the nomination papers from candidates of ruling government. This led to boycotted of elections in some parts of the country (Ademoyega, 1989). At the end, Nigeria had a constitutional crisis to the extent that for three days, there was no head of government as the President; Dr Nnamdi Azikiwe found it difficult to reappoint Balewa as Prime Minister (Iyayi, 2007). A similar case was recorded at regional level where the process of changing 
government was characterized by series of violence. These crises eventually led to the first military coup in 1966.

The 1979 transition program produced the so called two third (2/3) controversy. Given the fact that the military supervised the transition program, there was not much violence, but the result of the election attracted criticism as the Supreme Court delivered a controversial judgment on the winner as reported Iyayi (2007). However, the second stage of the crises was seen during civilian to civilian transition in 1983 where the results of elections were distorted in many parts of the country. The results of the elections were rejected by the parties and the crisis provided the opportunities for the military to stage another coup on December 31, 1983.

The aborted third republic witnessed what is called transition without end in Nigeria. Though, the government organized the most secured, peaceful, and free and fair elections in Nigeria's history. Open Ballot system (OBs) was adopted due to past elections history and experiences in the country. The OBs required voters queuing behind the candidate or his poster as the electoral officer counts the voters directly on the queue. At the end of the day, President Babangida annulled the presidential election.

Again in 1999, because the military oversaw the transition, there was little violence despites irregularities recorded during the election which brought Chief Olusegun Obasanjo to power in May, 1999. This was attributed to determination of both the people and politicians to end the military rule in Nigeria. The preceding 2003 general elections which were conducted under civilian government were characterized by fraud. Evidence made available showed that irregularities distinctively characterized the elections. The Transitioning Monitoring Group (TMG) (2003) reported that as the voters waited to cast their vote in the polling stations, the political class and political parties had different ideas. The voters wanted their vote to determine the winners of elections, while the political class wanted to corrupt the process and rig their way into elective offices. The elections both at federal and state as well as local government, according to TMG (2003) were characterized by threats of assassination of several political opponents. Strangely, some political candidates who did not stand for elections were returned as having won elections. These irregularities were accompanies by multiple, ghost and underage voting, violence, intimidation and harassment, stolen ballot boxes, vote buying, disruption of polls, absence of electoral officers.

Since inception of democracy in 1999 up to 2011, the governments in power and politicians have had their own designs and have generally perpetrated and maintained a culture of electoral violence and warfare (Iyayi, 2007). All conducted election is not 
free of tension and controversy either before during and after elections. The country hoped for a better election in 2007, believing that because the President had served his two terms, the incumbency factor would be greatly reduced. But as the election period drew near the President and Ruling party see 2007 general election as do or die affair. These actions of the President and his party made the 2007 election the worst in Nigeria's electoral history, surpassing the events of 1965-1966 (Iyayi, 2007). Meanwhile, the nature of the electoral violence had changed, though before 2003, it was executed by party thugs. But from 2003 especially in 2007, godfathers, governors, local government chairmen and candidate for legislative houses recruited followers, thugs and assassins armed with sophisticated weapons and unleashed them on their opponents and on society (Omotola, 2007). The nature of Nigeria elections the role of Nigerian laders during election was captured by Egbokare (2007) as:

Since 1979, things appeared to be getting worse. I think what was different this time was that it was not just a thug affair. Governors and their Deputies, Ministers, in fact, the high and mighty in the society were involved in the operations once left to thugs. They personally participated in snatching ballot boxes, thumb printing, and disruption of voting. The police as usual provided cover. The reason these individual got involved directly was because thugs were neutralized by the people's resolve in a number of places. In one instance, the police and thugs of a certain party had dispersed voters with tear-gas and were thumb printing. In another instance, voting stopped at a polling station after only three people had voted. Voter intimidation was rampant, ballot boxes were burnt, fire arms were freely used and of course lives were lost.

The most unfortunate side of this review of the nature of electoral system in Nigeria is that things are not improving. Instead, they are getting worse politicians, electoral administrations and government at all levels is not learning any useful lessons from history.

\section{Challenges for Democratic Succession in Nigerian Fourth Republic}

Many political leaders did not comply with the legal framework for succession. It is established fact that most of the politicians 'deliberately ignore laid down rules and procedure, in some cases it become undemocratic to even discuss succession plans (Hameso, 2002). Democratic leaders are so tense about power to the extent that existing constitutional provisions, party rules and procedures are altered. At the top this problem is the scant respect that many of these political leaders have for the constitution and constitutionalism (Rawlings, 2008). In 2007 for instance, Former 
President Obasanjo attempted to change the constitutional provisions aimed at paving his way for a third term in office. This created tension before and after 2007 general elections to the extent that those who oppose his (Obasanjo) decision were subjected to series of victimizations.

Similarly, the zoning political arrangement was designed by ruling party for smooth leadership succession at inception of fourth republic. This arrangement according to the party is to cater for the interest of both minority and majority ethnic groups in the country. But the beneficiaries (politicians) of this political arrangement (zoning) refused to observe and abide by the zoning rules as entrenched in the party's constitution. As Nigeria prepared for presidential elections in 2011, the political arena was engulfed by tension as President Jonathan jettisoned the zoning principle. This generated a lot of debate and litigation. The president and his ally argued that Nigerians should opt for competence and merit instead of sectional leadership which the zoning is assuming to present. Others based their argument on the fact that zoning is antithetical to both constitutional and fundamental human rights of President Jonathan to exercise his franchise irrespective of his ethnic origin. It can be recalled that zoning principle which was jettisoned by President Jonathan served as ladder he padded to the top. The aftermath of zoning jettison is the rejection of elections results which eventually led to post election violence in some part of the country.

Politics continued to be seen by the politicians not as a call to service but as a clearing house for jobs, contract and official plunder (Bassey, 2008). Since winners, according to Hameso (2002), holds key to society's economic and social resources, to win an election means that you, your village, tribe, or region obtains all the top posts (Mackintosh, 1965). Ake asserted that:

Those who win state power can have all the wealth they want even without working, while those who loss the struggle for state power cannot have security in the wealth they have made even by hard work. The capture of state power inevitably becomes a matter of life and death. That is one reason why our politics is so tense, anarchic and violent (Cited in Bassey, 2008).

These benefits contributed in no measure to the willingness of those in power not to concede electoral victory to the opposition (Hameso, 2002). For instance, all the political parties, especially the PDP and their governments used both fair and foul means to put their party members in power. The party primaries were characterized by the fraudulent practice of imposing and replacing candidate by the party leadership. These activities invariably threatened the parties and therefore the survival 
of democracy as people were resolute in instituting both legal and illegal means in order to reclaim their stolen rights.

The cultural attitudes toward leadership in Africa, according to Baffour (2003), hinder smooth political succession. Leaders see themselves on top of the people they govern. They also view as people who were born to rule till death. The people also sadly aided this undemocratic attitude as they see these so-called political leaders as either 'Father of the Nation' or God's appointee. Some of these leaders on the other hand and more tragically to see opponents as enemies of nation and anti-people. Some politicians justified the actions by equating the political kingdom with heaven. These attitudes prompted the politicians to conclude that there is no vacancy in the Presidential or Governor's loge whenever the election is approaching. They prevent competition in the election to fill the vacancy; they encourage violence to achieve their end; they use police and other security agencies to rig, if need be (Omoruyi, 2007).

The ideology of political leaders is another factor that hinders smooth succession in Nigeria and other African states. Recall from the past, majority of politicians today are one time in the cabinet of undemocratic government who at initial stage has no passion for democracy. They did everything possible to undermine democracy in the past. The behavior of politicians has given the impression that they are not tolerant of opposition parties. The politician's behavior, conduct and even their statement suggests that the rules of the game and opposition parties do not exist. The PDP determination to hold power forever is a good example. This PDP's position was buttressed by Ogbulafor (former National Chairman, PDP) as he said: "The PDP is a party for all and it is set to rule Nigeria for the next 60 years. I don't care if Nigeria becomes a one party state. We can do it and PDP can contain all" (Samuel, 2008). Thus, on what ground can we have smooth and acceptable succession in Nigeria when the Obasanjo (former President and leader of ruling party) sees political opponents as anti-people and as enemies of State? Obasanjo indeed share no belief in multi-party democracy, therefore he has little or no reason to sustain it. In the past, before becoming democratic elected president of Nigeria, he posited that:

...a one party state appears to be the only procedural mechanism through which we can transcend the divisive and centrifugal forces tearing us apart and diverting our attention from the monumental task of integration and nation building. One party system as our national rallying point would give us continuity and structural change, continuity and stability as regards fundamental policies and objectives... (ICG, 2007a) 
Throughout his tenure, the logic of such position was not difficult to conceal as Obasanjo led PDP government did everything possible to see that Nigeria transformed into a one party state. Thus, the conduct of political leaders while in office and their belief that to do their best on the job is the major factor prompting them to adopt even undemocratic measures to retain the power. Highly corrupt leaders according to Baffour (2003) would alter the process of succession once they don't trust the successor; engage in gerrymandering to anoint a successor whom they hope to control. For instance, to further buttress this, President Moseveni declared:

I'm not ready to hand over power to people or groups of people who have no ability to manage a nation... why should I sentence Ugandas to suicide by handling over power to people we fought and defeated? It's dangerous despite the fact that the constitution allows them to run against me... at times, the constitution may not be the best tool to direct us politically, for it allows wrong and doubtful people to contest for power. (Cited in Hameso, 2003)

The ruling party (PDP) in Nigerian shares the same position with similar parties in Africa. The then President Obasanjo claimed that the reform programme which the PDP led government have started, need to be continue by those taking over (Vanguard, 2007). The utterance of succession procedure is also attributed to the attempt on part of the politicians to cover the atrocities they have committed while in office. They do everything possible to ensure the victory of their anointed candidates. This anti- democratic nature of fourth republic politicians which undermine the smooth transfer of power was captured by Omoruyi, (2007) as follows:

1. The Nigerian politicians generally do not have faith in the ballot box.

2. The Nigerian politicians do not believe that they could lose an election

3. The Nigerian politicians who glaringly lost an election or were rejected by the voters in their various communities still go to the tribunal and cry foul that their opponents or the management of election or the government or the police robbed them of victory for their opponents.

4. The Nigerian politicians believe that wining is the only option in an election even if it is very obvious that the voters do not want them.

5. The Nigerian politicians believe that all is fair in elections.

6. The Nigerian politicians believe that election officers are purchasable and could be bought to deliver victory to the losing party.

7. The Nigerian politicians do not believe that there would be another election 
8. The Nigerian politicians believe that they are only involved in the last election.

9. The Nigerian politicians do not believe that one could work for and actually earn votes in an election based on one's appeal.

10. The Nigerian politicians do not believe that democracy is anchored on a series of elections.

11. Nigerians, especially those who call on Allah and God to show them the way do not seem to have faith in tomorrow and subsequent elections.

Excessive power the constitution seems to have given political leaders and politicians in Africa, especially Nigeria remains a salient challenge to smooth transfer of power. These excessive powers encourage what Bassey (2008) called 'prebendal politics'. By prebendal politics, the political offices should be competed for the personal benefit of office holders and their supporters. The behavior of most of these leaders clearly illustrates Bassey's position. Besides the award of contracts as well as the maneuvering of security agencies, the control of the electoral management bodies constitute the other challenges that hinders smooth transition from one government to the other as declared Baffour (2003). The constitution entrust the appointment of principal electoral official to the President. This made the manipulation of the electoral bodies by the ruling party easier. Equally, as well, orderly succession in fourth republic became a do or die affair with the politicians resolutely determined to 'win' at all cost

Similarly, the role of elections management bodies at various levels is another factor that hinders successive transfer of power in Nigeria. Section 153 of the 1999 constitution establishes the Independent National Electoral Commission (INEC) to conduct election within the general framework of the law. The commission was accused of being part of the monumental frauds that characterized the fourth republic elections (Iyayi, 2007). INEC therefore exhibited gross partisanship in handling electoral matters. The Commission was involved in issues that were outside its scope and constitutional responsibilities and in the process displayed its partisan preferences. Acting on the prompting of the EFCC and the Presidency, it disqualified some candidates (Ajetumobi and Kehinde, 2007). However, many of those disqualified before the Supreme Court judgment were being denied their legitimate right to contest the election (ICG, 2007b).

Non-compliance of INEC with respect to some key rules, also shows that the constitution can provide directions for the national development and self realization, 
but, the pace at which the development takes place depends on institutional operators and society (Ghali, 2009). For these reasons, Anifowose therefore concluded that;

Free elections depend more on the attitude of candidates, voters and government than on the drafting of electoral laws ... Elections only work because we believe they are going to work as long as it is understood that the maintenance of legitimacy through such tricks as election is a basic concern of all governments. (Anifowose, 2006:203)

Implementing succession programmes is therefore not only about constitutional provisions but about the inculcation of a culture of respect for the laws guiding it; acceptance of rulings by the courts and giving effect to judicial decisions. These observations suggest that INEC and similar such bodies have directly and otherwise contributed to the problem of succession in Nigeria.

\section{Conclusion}

Based on the submission of this paper, leadership succession in Nigeria has always been accompanied by high tension since inception of democracy in 1999. The evidence gathered indicate that the political elites failed to obey the rules that guide the conduct of election in the country. The attitude of politicians coupled with the benefit attached to the political offices prompted the political office seekers to ignore the rules governing the process of smooth change-over. The process was also characterized by series of political assassinations and riots. Election rigging was a also a prominent feature in the process. Thus, to have a smooth transition or change of government, all the parties involved (Politicians, INEC, Security agents, judiciary and Citizens) in the process must be committed towards ensuring free and fair elections.

\section{References}

Ademoyega, A (1981). Why We Struck. The Story of the First Nigerian Coup. Ibadan: Evans Publishers

Adejumobi, S and Kehinde, M (2007). Building Democracy without Democrat? African Journal of Elections Vol. 6(2).

Anifowose, R (2003). Theoretical Perspectives on Elections. In R. Anifowose and T. Babawale (eds.) 2003 General Elections and Democratic Consolidation in Nigeria. Lagos: Friedrich Ebert Stiftung and Frankad Publishers.

Anifowose, R (2006). Violence and Politics in Nigeria: The Tiv and Yoruba Experience. Lagos: First Academic Publishers. 
Anise, L. (1974). 'Trends in Leadership Succession and Regime Change in African Politics since Independence' African Studies Review 17(3).

Bassey, O. C. (2008). "Legislature-Executive Relations and the Future of Democracy in Nigeria" in Ojo, E.O. (ed.) Challenges of Sustainable Democracy in Nigeria, Ibadan: John Archers Publishers Ltd.

Dudley, B (1982). Introduction to Nigerian Government and Politics, Lagos: Macmillan

Egbokare, F. (2007). 'Dancing Naked in the Streets' Sunday Tribune 22 April.

Egwemi, V. (2010). A Decade of Democracy in Nigeria, 1999-2009: An Introduction to the Key Issues in V. Egweni (ed) A Decade of Democracy in Nigeria, 1999-2009 Issues, $\quad$ Challenges and Prospects of Consolidation.

Ghali, Y (2009). "Decreeing and Establishing a Constitutional Order: Challenges Facing Kenya". www.cs/s.ox.ac.uk/otjr.php

Goldsmith, A.A. (2000). "Risk, Rule and Reason: Leadership in Africa". Public Administration and Development Vol. 21

Goodwin-Gill, S.G. (2006). Free and Fair Elections New expanded edition. Published by Inter-Parliamentary Union

Hameso, S. (2003). 'Issues and Dilemmas of Multi-party Democracy in Africa', West Africa Review

ICG (2007a). "Nigeria's Elections: Avoiding Political Crisis". Africa Report No 123 28 March .

ICG (2007b). Failed Election's Failing State? Africa Report No 126, 30 May.

Ijim-Agbor, U (2004). "Democracy and Electoral Malaise in Nigeria: Towards an Effective Approach to Free and Fair Elections". African Journal of Political and Administrative Studies, Vol. (1)1

Iyayi, F (2007). "Elections, INEC and The Problem of Election Mindsets in Nigeria". The Electoral Journal Vol. (1)1

Jonari, J.C (1978). International Relations and Politics: Theoretical Perspective. India: Sterling Publishers Private limited.

Mackintosh, J.A. (1965). The Struggle for Power in Nigeria. Transition 22

Mackenzie, W.J.M (1958). Free Elections. London: Geoge Allen and Unwin. 
Ojo, E.O (2007b). "Elections: An Exploration of Theoretical Postulations". African Journal of Elections, Vol. 6(2)

Omoruyi, O (2007). "Political Education for the Political Class", in Hassan Saliu, Ebele Amali and Raphel Olawepo (eds), Nigeria's Reform Programme: Issues and Challenges. Ibadan: Vantage Publishers Ltd.

Omotola, J.S. (2007). "Godfathers and the 2007 Nigerian Elections". African Journal of Elections, Special Issues: Nigeria's 2007 General Elections 6 (2)

Rawling, J.J. (2008). "Challenges for Democracy in Africa". A paper presented at $5^{\text {th }}$ Annual Trust Dialogue, Abuja, on 17th January.

http://www.ghanaweb.com/GhanaHousePage/NewsArchive/artikel.php?ID $=138296$. Accessed on 3/9/2011

Vanguard, 12 February 2007:15. 